\title{
Resource Extraction in the Territories of Indigenous Peoples: The Quest for Cultural Rights
}

\author{
Apparao Thamminaina \\ National Institute of Technology, Rourkela, India
}

\begin{abstract}
The rapid industrial growth amidst the resource-rich habitats of indigenous people results in an unprecedented and inescapable influence of the other. Most often, such interactions are exploitative for the indigenous communities. Besides this, the development induced displacement escalate the fear of loss of “cultural practices” among the indigenous peoples. The "official" argument often confines to the fact that the people are displaced with better facilities to a place few kilometres away from the original habitat. Such an argument forces to establish harmony between development and the displaced and ignores cultural rights and customary boundaries. In such cases, indigenous peoples negotiate for the protection of cultural rights with the corporate establishments and statutory bodies using a variety of means. This idea is explored in the context of the resistance movement organized by the indigenous Kondhs of Niyamgiri region of Odisha, India.
\end{abstract}

Keywords: indigenous peoples, cultural rights, identity, development, Kondhs

\section{Introduction}

The indigenous people of India have survived against all odds in the history. Their identity maintained over generations despite the colonization of their territories or the interaction with modern society. Although the status of indigenous or aboriginal is contested in Indian context, it is primarily attributed to those communities identified as Scheduled Tribes (STs) by the government of India. The indigenous peoples of India prefer to identify themselves as Adivasi (first inhabitants) or Vanavasi (forest dwellers). The claims and aspirations of indigenous communities may widely vary. But their common ground is a quest for the preservation and flourishing of a culture tied to their ancestral land (Wiessner, 2011). The colonial administration recognized the relationship between forest and adivasis and had a specific category "forest tribes" in the Census Report 1881 (Xaxa, 1999). The symbiotic relationship between tribal communities and forests has been widely discussed in the literature. Their relationship with forest is not limited to economic aspects but play a pivotal role in cultural attributes. This intricate relationship is the issue of special concern in relation to the dispossession caused with the establishment of industrial development projects in the adivasi habitats of the country.

The constitution of India ensured rights and privileges to those identified as Scheduled Tribes (STs) by the government of India. But, violation of rights by various agencies is the significant cause of unrest. The debates on the idea of indigenous people and their rights and privileges are relevant in this context. Roy Burman (2009,

Apparao Thamminaina, Ph.D., Assistant Professor, Department of Humanities and Social Sciences, National Institute of Technology. 
p. 1) rightly says, "One of the prime factors for claiming aboriginal or indigenous status for the tribes is to enable them to gain territorial, land rights and control over natural resources". However, there is no mechanism to identify indigenous people. Few communities of the country are identified as STs. But, all the STs need not be indigenous people. The problem of recognizing few people as indigenous is there all across the world because of lack of clarity on the criteria. The debate around lost tribes of Europe raises similar concerns. As Kirsch (1997, p. 64) rightly points in the case of Amazonian and Melanesian tribes, "societies that are identified as lost tribes may gain advantages from their new-found status. If the 'lost tribe' label is discredited, these societies stand to lose access to the special privileges that this status can confer”. Therefore, privileges from the State helpful to these communities in order to protect from any agency that causes harm and make the people vulnerable.

\section{Kondhs of Niyamgiri}

Kondhs are the indigenous inhabitants of Niyamgiris hills and forest. They are identified as Primitive Tribal Group (PTG) [renamed as Particularly Vulnerable Tribal Group] by the Government of India. Kondhs of this region are divided into three endogamous categories. They are: Dongria Kondhs, Kutiya Kondhs, and Jharnia Kondhs. Cultural and ethnographic aspects of Kindhs are well documented in several ethnographic works (Patnaik, 1981; Sarkar, 1981; Nayak, Boal, \& Soreng, 1990; Aparajita, 1994; Jena, Pathi, Patnaik, \& Seeland, 2006). Dongrias lives on the hills in the interior forest and entirely depend on the forest for livelihood. Jharnias live near the streams and depend on forest (Minor Forest Produce) for livelihood. Kutiyas live at foothills; partly depends on forest and partly on agriculture. Kondhs speak Kuyi language but part of the population speaks Odiya too. Since a majority of the population depending on the forest for livelihood; their life is intricately interwoven with nature. These nature worshippers believe that the God exists everywhere in the forest. All the objects of nature, that is: the hills, stones, trees, and streams have supernatural power. The entire Niyamgiri ranges of mountains are sacred for them. Therefore, they maintain a harmonious relation with all the objects of nature. They use the products of nature judiciously. They have not yet completely got into the surplus based production system. Their lifestyle is marked by discipline and co-operation. They often move in groups to collect food from the forest. The collective consciousness occupies the front stage in all their social interactions.

\section{Cultural Rights of Indigenous People}

Article 1 of the International Labour Organisation's “Convention concerning Indigenous and Tribal Peoples in Independent Countries" (ILO No. 169) defines indigenous peoples as those "people in independent countries who are regarded as indigenous on account of their descent from the populations which inhabited the country, or a geographical region to which the country belongs, at the time of conquest or colonisation or the establishment of present state boundaries and who, irrespective of their legal status, retain some or all of their own social, economic, cultural and political institutions". Further, the ILO Convention states that "self-identification as indigenous or tribal shall be regarded as a fundamental criterion for determining the groups to which the provisions of this Convention apply" (Article, 1). In other words, being indigenous is what people can regard themselves as being (or not being). Such criteria are ambiguous. The definition of ILO may not be applicable for many countries where the emphasis is not on the country as a whole. The contested histories of migration and the claims and counterclaims of people play a pivotal role. The Indian government 
identifies people into various categories based on socio-economic criteria. In such categorization, idea of indigenous is closely identified with Scheduled Tribes (ST) although not necessarily the same. Therefore, in the Indian context, it becomes a socially constructed identity with reference to putative similarity or difference (Jenkins, 1996, 1997) and it is to be complicit in a history of somebody else's making (Sundar, 1997). A more inclusive understanding of indigenous communities emerged from Kennewick debates. The debates suggest four interwoven strands in "indigenous". In the first, the term suggests association with a particular place (usually lengthy)—a locality, a region, a country, a State...second, "indigenous” is synonymous with prior inhabitation...third, "Indigenous" also carries a sense of original or first inhabitants...a fourth strand accounts for indigenous peoples as distinctive societies (Thornberry, 2002, pp. 37-39). The last part is very important as well as very complex. It is difficult to identify several communities as indigenous or not in the context of their absorption into "mainstream" society. Therefore, the question of who is indigenous and who is not, becomes a political question, a question of representation rather than of fact (Fernandes \& Thukral, 1989). Another important debate is the similarity or the difference between "tribal" and "indigenous". In this context, ILO Conventions distinguish "tribal" from "indigenous"-the former term takes much of the burden of the distinctive society, while the latter is expressed as a historical priority (Thornberry, 2002, p. 39). The important question here is, whether all the tribes are indigenous or not? The answer depends on the socio-political context of a country and varies accordingly.

Regardless of the identification as "indigenous" or "tribal" or both, the identity in the welfare state is associated with the rights and privileges. Article 20 of the UN Declaration on the Rights for Indigenous Peoples (2008) recognizes "the right to be secure in the enjoyment of their own means of subsistence and development, and to freely engage in all their traditional and other economic activities". The spirit of this article further emphasized through the Article 26 of the same Declaration which states "Indigenous peoples have the right to the lands, territories and resources which they have traditionally owned, occupied or otherwise used or acquired". The signatories have to abide by this declaration, although, it is not a strong legal binding. In a recent press release (8th August 2017), the United Nations states "But a decade on, we need to acknowledge the vast challenges that remain. In too many cases, indigenous peoples are now facing even greater struggles and rights violations than they did ten years ago" . India has a long history of protecting the rights of "indigenous" and/or "tribal” communities. It should not compromise on the same spirit. But, an adivasi ("original inhabitant") and/or those identified as scheduled tribes by the Government of India constitute a large percentage of those displaced or destroyed by the current capitalist mode of development (Fernandes \& Thukral, 1989). Besides this, the non-tribal immigrations into the tribal areas changed the demography of the regions inhabited by adivasis (Sundar, 1997; Apparao, 2012). As a result, the socio-political and economic identity of the people of these regions is blurred. The claims of the people with or without recorded proofs often add confusion to this scenario.

Niyamgiri hills and the forest is not merely a resource but a sacred world for the Kondhs. Their ideas of resource use and resource management do not aim for surplus. As Rose (2005, p. 303) argues, the philosophy of aborigines reveals, "Rather than humans deciding autonomously to act in the world, humans are called into action by the world. The result is that country, or nature, far from being an object to be acted upon, is a self-organising system that brings people and other living things into being, into action, into sentience itself”.

${ }^{1}$ Retrieved from http://www.un.org/en/events/indigenousday/pdf/Press\%20Release\%20Indigenous\%20Day\%202017.pdf. 
Such philosophy of aboriginal communities reflects in their day-to-day life. Since nature is treated as sacred, the encroachers or whoever harmful to nature are treated as profane. For example, Kondhs consider those NGOs fight for the protection of nature as sacred and the government and private agencies which extract resources as profane. Although indigenous communities use resources, they do it for subsistence. They are rational in doing the same. They believe in the sustainable use of resources. At the same time, the resources have not got destroyed since a small population depends on them for subsistence, not for surplus. Their traditional knowledge helps them to establish a harmonious relation with nature. Therefore, treating indigenous communities as natural conservators is not an overstated idea. The entry of non-tribals into the resource rich regions inhabited by adivasis and their philosophy of maximization of profit led to the destruction of natural resources but not the use of resources by adivasis. Adivasis resists such attempts and treats outsiders as profane.

\section{Violation of rights}

Sterlite Transmission Ltd (2001) or Vedanta Resources (2004) or Sesa Sterlite Ltd [SSL] (2007) ignited conflict among people, state and non-state actors in Niyamgiri region. The Greenfield aluminium refinery at Lanjigarh became operational in 2008. As per company's claim "In January 2009, SSL was awarded the ISO 9001:2008, ISO 14001:2004 and OHSAS 18001-2007 certificates for adopting global standards in quality, environment and health and safety systems" ${ }^{2}$. SSL also claim: "The company strives to facilitate the socio-economic transformation of local communities around Jharsuguda and Lanjigarh through concerted efforts in the spheres of health, education, livelihood, infrastructure and environment”3. However, the objective is not achieved, probably, due to the huge void between the understanding of the company on local communities and the reality. For instance, the name Vedanta, as described by the company, "originated from the philosophy taught by the Vedas, the most ancient scriptures of India. The word 'Vedanta' means 'ultimate knowledge' and helps an individual gain the knowledge of his or her intrinsic self. This knowledge helps individuals lead the life of peace, harmony and bliss". ${ }^{4}$ But, the company was not really successful in building peace and harmony with the indigenous peoples. The Kondhs resisted against the extraction of minerals in Niyamgiri hill ranges. At the same time, their slogan of ensuring participation of local communities in the development process was not successful, probably such idea of development is a misfit in the worldview of Kondhs.

The rights of the Kondhs of Niyamgiri are totally ignored while granting the environmental clearance for the aluminium refinery (Amnesty International, 2010; Padel \& Das, 2010). The people have deep concern about the impact of mining on Niyamgirimountain, from which they derive many of the religious beliefs and cultural practices that define their identity (ActionAid, 2007). They are also afraid of displacement and loss of livelihoods with the industrial establishments for mining. The Kondhs believed that the industry will conduct mining activities around most of the hills in the years to come and nothing would be available for people. The toxic substances from red mud pond of the Vedanta company leaked into Vamshadara river due to the cracks to the red mud pond during heavy rains ${ }^{5}$. It polluted the water bodies in the vicinity and caused health hazards to the people and animals. However, the company claims that there are no toxic substances present in the water

\footnotetext{
${ }^{2}$ Retrieved from http://www.un.org/en/events/indigenousday/pdf/Press\%20Release\%20Indigenous\%20Day\%202017.pdf.

${ }_{3}^{3}$ Retrieved from http://www.un.org/en/events/indigenousday/pdf/Press\%20Release\%20Indigenous\%20Day\%202017.pdf.

${ }^{4}$ Retrieved from http://www.vedantaaluminium.com/vision-values.htm.

${ }^{5}$ Retrieved from http://www.downtoearth.org.in/news/vedantas-red-mud-pond-leaks-into-vamsadhara-river-33296.
} 
bodies of the region ${ }^{6}$. This reflects the failure in assessing the potential impact of the mining project on people and the ecosystem. This incident escalated fear among the people. They are scared with the rumours spread in the region describing the possible catastrophe in future.

The attempts to extract minerals from resource-rich tribal regions are not new. It is essential to understand the purpose and the process of such activities. The Panchayat Extension to Scheduled Areas (PESA) Act ${ }^{7}, 1996$ and the Forest Rights Act (FRA), $2006^{8}$ made a number of provisions to ensure the rights of tribal people on their land and resources. The FRA 2006 made it mandatory to conduct Gram Sabha (village council meeting) and take its approval to establish any industry in the Scheduled Areas ${ }^{9}$ of the country. The company has documentary evidences for conducting gram sabhas. But, people of Niyamgiri says, the company did not conduct Gram Sabhas. Voluntary organizations alleged the company for forging ${ }^{10}$ Gram Sabha resolutions. This reveals the violation of the rights of the people of Niyamgiri region in the process of establishing mining company. The Kondhs resisted the same. But, the resistance was overshadowed for a long time by the aluminium giant. In such condition, Kondhs joined hands with various voluntary organizations to strengthen their movement against the company. The contribution of people is more important in this context since no agency can build a sustainable people's movement without the active participation of people.

\section{Niyamgiri Surakhya Samiti (NSS)}

NSS is a collaborative organization or a joint action group of the people and NGOs to fight against the mining establishment. Kraemer, Whiteman, and Banerjee (2013) discussed the dynamics of organizing and counter-organizing processes around anti-corporate mobilization and the significance of national and transnational advocacy networks in the Niyamgiri movement. The source of funding to the people's movement was in debate. A funding agency cannot really build a sustainable people's movement with mere sponsorship. It is true in the case of government agencies too. Neither the government agencies nor the political parties are in a position to build a sustainable people's movement in favour of "development" if the same is detached from the people's idea. Therefore, trying to identify funding agencies as the obstacles for national development is a worthless task. Instead, it is fruitful to examine the causes and consequences of a people's movement against a project which meant for the economic development of the nation.

\section{Saxena Committee Report and Supreme Court Judgement}

Ecological significance of the territory is vital since its use for mining leads to the imbalance in the eco system. The Saxena committee report (2010) vividly states, “The proposed Mining Lease (PML) area, which lies on the upper reaches of the Niyamgiri hills, is surrounded by dense forests and is the habitat for diverse species of plant and animal life" (Saxena et al., 2010, p. 1). The report emphasized on the people and their eco-system. It has also revealed the fact that the Niyamgiri is not only a habitat but a source of life and livelihood for Kondhs. It provides the basic needs such as water, food, and medicine to the inhabitants. The report mentions, "The two [Dongria Kondh and Kutiya Kondh] communities regard the Niyamgiri hills as sacred and believe that their survival is dependent on the integrity of its ecosystem” (Saxena et al., 2010, p. 2).

\footnotetext{
${ }_{7}^{6}$ Retrieved from http://www.vedantaresources.com/media/161444/vedanta-red-mud.pdf.

7 Retrieved from http://tribal.nic.in/WriteReadData/CMS/Documents/201211290242170976562pesa6636533023.pdf.

${ }^{8}$ Retrieved from http://tribal.nic.in/WriteReadData/CMS/Documents/201211290332077861328File1033.pdf.

${ }_{9}^{9}$ Retrieved from http://tribal.nic.in/Content/DefinitionofScheduledAreasProfiles.aspx.

10 Retrieved from http://www.kractivist.org/india-making-a-hollow-in-the-forest-rights-act/.
} 
This is a critical point to understand the causes and consequences of the people's movement.

The report of Saxena committee laid the foundation for the historic judgment by the Supreme Court of India. PESA Act, 1996 and Forest Rights Act, 2006 are also instrumental in arriving at the decision to conduct Gram Sabha to hear the voices of people for the in-depth scrutiny into the issue. The Supreme Court of India in its historic judgment ordered for 12 Gram Sabhas. In its judgment (2013, pp. 78-79), Supreme Court of India opines, "We are, therefore, of the view that the question whether STs and other TFDs [Traditional Forest Dwellers], like Dongria Kondh, Kutia Kondhs and others, have got any religious rights, i.e., rights of worship over the Niyamgiri hills, known as Niyamgiri, near Hundaljali, which is the hill top known as Niyam-Raja, have to be considered by the Gram Sabha. Gram Sabha can also examine whether the proposed mining area Niyam Dangar, $10 \mathrm{~km}$ away from the peak, would in any way affect the abode of Niyam-Raja. Needless to say, if the BMP [Bauxite Mining Project], in any way, affects their religious rights, especially their right to worship their deity, known as Niyam Raja, in the hills top of the Niyamgiri range of hills, that right has to be preserved and protected. We find that this aspect of the matter has not been placed before the Gram Sabha for their active consideration, but only the individual claims and community claims received from Rayagada and Kalahandi Districts, most of which the Gram Sabha has dealt with and settled”. In this context, Government of Odisha conducted twelve meetings in the Niyamgiri region in Rayagada and Kalahandi districts.

\section{Niyamgiri Gram Sabha}

Dispute resolution is a communitarian activity since time immemorial. However, it was the responsibility of few knowledgeable elders of the community in traditional societies. They strive for a peaceful and agreeable solution for all the people involved in the dispute. Gram Sabha is the similar mechanism. This is not only a reflection of the practices of people but also builds confidence in the statutory bodies of the country. In a way, it increases their participation in the activities of statutory bodies. Niyamgiri Gram Sabha (Niyamgiri Village Council) is a result of the long struggle by people, activists, institutions, non-government organizations and other voluntary agencies. Media played an important role in keeping the issue in public domain. The purpose of Gram Sabha is to examine the violations and restore the rights of people over land and resources. The people, guided by NGOs believe that the claims of Vedanta Mining Corporation on environmental impact assessment are totally false. It led to the resistance by people with the support of voluntary organizations. Saxena committee's report strengthened the claims of Kondhs and other traditional forest dwellers. The people participated in Gram Sabhas not because of fear and the huge presence of security forces, but because of the process itself. Many people explicitly mention that "Government came to our hamlets for the first time”. The process of Gram Sabha aimed at putting the people first. But, the trust deficit between the state and forest dwellers still exists. The state must make efforts to fill this gap. However, it is not an attempt to say that the government is practicing the policy of exclusion but to emphasize the need to take up an inclusive policy which is meaningful to its people. Gram Sabha is definitely an effective tool to bridge this gap if it addresses the aspirations of people without prejudice.

All the Gram Sabhas were organized on time, at the designated places as displayed at panchayat office, schools, block office and other spaces of a village. The Gram Sabha was chaired by the Sarpanch (head of the village council) or ward members (member of the village council) of a respective village, the District Magistrate was the observer at every meeting and the documentation was done by the respective Gram Sevak. The primary school teachers of the nearest schools were the translators. A videographer appointed by the state 
government to record the proceedings. The state police and Special Operations Group personnel were looking after security as the places are known for Maoist activities. Everyone is allowed to attend the meeting and observe the proceedings but the people in the voter list of the village were allowed to speak. After taking consent from the Sarpanch or ward member and magistrate, the gram sevak read out the objective and purpose of the Gram Sabha and the order of the Supreme Court of India to conduct the Gram Sabha. Later, voters of the village are invited by their names to share their concerns. All the voters of the village got the opportunity to speak. After detailed deliberations, every village adopted a resolution. Such resolutions are approved by every Gram Sabha with the signatures of all the voters of the village. A copy of the resolution was given to the villagers for their reference. The essence of the resolution is almost same in all the Gram Sabhas. The resolution is "We will not allow any organization to dismantle Niyam Raja for any purpose".

The process is transparent and open to everybody. The situation at Gram Sabhas appear scary with the deployment of huge number of personnel for security. But, the people were very peaceful and co-operative. They have never disturbed or unnecessarily intervened in the proceedings. They have unanimously conveyed the message in all the Gram Sabhas. "This is our land...our Niyamgiri...and our deity, the Niyam Raja. He provides everything we need for a living. He (God) has created us but not this government. God is not asking us to leave this place. How can you (government) ask us to leave? Let our blood flow in Nagavali and Vamshadara, we will not leave this place". This is the most repeated statement along with a discussion on the importance of several minor forest products available in the territory. There is no other opinion. They have unanimously resolved for retaining territory and deity by denying any encroachment by outsiders. The meetings have not probed into any other issue because of the limited objective and scope of deliberations.

The people are very much concerned about their cultural and religious rights and their deity Niyam Raja. They are afraid that the mining project dismantles their deity and disturb their eco-system depending on which they have been living for centuries. The Niyam Raja is their king, father and God and the entire Niyamgiri hill ranges considered sacred. They also believe that the government may relocate them to another place but not their God. They insist that they do not need any documents for their land because they have been living there from time immemorial but the Acts of Government are very new. They say, "We know how to live and conserve mother forest and we don't need training from any agency”. They unanimously expressed anger upon insensitive encroachment in the name of development.

\section{Conclusion}

The huge mining project in Niyamgiri escalated the fear among the Kondhs. Their primary concern is the demolition of deity and displacement from habitat. The people believed that their customary rights are ignored by the government and the mining industry. They have actively participated in the resistance against the establishment with the belief that they will be displaced from the habitat and their livelihoods will be devastated in the near future with the explorations for mines. The displacement often dismantles the connections between people, resources, knowledge and customary rights. If so, the knowledge of the people on resource use and territory remain as history. The dissociation with traditional knowledge forces people to depend on "the other". Such dependency lands them in multiple vulnerabilities. Ironically, "the other" for development becomes the dependents on those who displaces them or representing the development. The other intersecting fact is that the indigenous peoples have a different worldview from those who displaces them. This worldview is the reflection of their social, political, economic, technological, and linguistic systems. The 
displacement process displaces such worldview too. The advocates of investment mediated development argue that the people are displaced with better facilities to a place few kilometres away from the original habitat. Such argument forces to establish harmony among people, knowledge, and resources. But the fact lies in the socio-political system of the displaced community. The traditional boundaries of indigenous people confine their movement to specific parts in the forest. They can gather food only from a territory belongs to a hamlet or group of clans. They are left with nothing if they are displaced from their territory. Therefore, displacement; whatsoever kind it is, denies customary rights and dismantles the linkages between knowledge and resources. In fact, it may escalate intra-community conflicts.

The economic progress is very important in the contemporary scenario. But, the development at the cost of "the other" is a pity idea. A careful assessment is necessary before initiating a development project to avoid disastrous impact on people. The development would be meaningful and long lasting if the concerns of all stakeholders addressed without bias. Ignoring the sensitivities of people results in the resistance, wastage of time, money and other resources. The resistance in Niyamgiri reveals the importance of traditional belief systems and customary rights. It reminds the fact that the government as a collective cannot ignore the concerns of any of its components, either smaller or bigger. The damage caused by the state need to be addressed by the same. Therefore, it must make an attempt to understand the cultural practices, livelihood system and the relation between the people and environment to address their concerns. Another important aspect is to understand the political aspects of indigenous people. Traditionally, indigenous communities consider themselves as separate political entities. This idea sustains, if not in entirety, despite the implementation of the integration policies since colonial rule. They continue to resist the overwhelming presence of outsiders in their territories treating them as "the other". The authority accompanied by the assertion of "the other" and the state continue to be the source of conflict. The integration of tribes with rest of the society or "mainstreaming" them in the name of development will not give desired results if it fails to address the aspirations of people. The people are afraid of the loss of identity with the influence of varied economic, political and ideological factors. Therefore, the development policy of India must be attentive to reduce the negative consequences on indigenous peoples.

\section{References}

ActionAid. (2007). Vedanta cares? Busting the myths about Vedanta's operation in Lanjigarh, India. Retrieved January 18, 2017, from https://www.actionaid.org.uk/sites/default/files/doc_lib/vedanta_report.pdf

Amnesty International. (2010). Don't mine us out of existence: Bauxite mine and refinery devastate lives in India. London: Amnesty International.

Aparajita, U. (1994). Culture and development: Dongrias of Niyamgiri. New Delhi: Inter-India Publications.

Apparao, T. (2012). Ethnic identity, cultural diversity and processes of change: A study of the chenchus of Andhra Pradesh, India. Hyderabad: University of Hyderabad.

Fernandes, W., \& Thukral, E. G. (1989). Development, displacement and rehabilitation. New Delhi: Indian Social Institute.

International Labour Organization. (1989). C169 - Indigenous and Tribal Peoples Convention, 1989 (No. 169). Retrieved December 15, 2016, from http://www.ilo.org/dyn/normlex/en/f?p=NORMLEXPUB:12100:0::NO::P12100_INSTRUMENT_ID:312314

Jena, M. K., Pathi, P., Patnaik, K. K., \& Seeland, K. (2002). Forest Tribes of Orissa: The Dongaria Kondh (Vol. 1). New Delhi: D K Print World.

Jena, M. K., Pathi, P., Patnaik, K. K., \& Seeland, K. (2006). Forest Tribes of Odisha: The Kutia Kondh (Vol. 2). New Delhi: D K Print World.

Jenkins, R. (1996). Social identity. London: Routledge. 
Jenkins, R. (1997). Rethinking ethnicity: Arguments and explorations. London: Sage.

Kirsch, S. (1997). Lost Tribes: Indigenous people and the social imaginary. Anthropological Quarterly, 70(2), 58-67.

Kraemer, R., Whiteman, G., \& Banerjee, B. (2013). Conflict and Astroturfing in Niyamgiri: The importance of national advocacy networks in anti-corporate social movements. Organization Studies, 34(5-6), 823-852.

Ministry of Law and Justice. (2007). The scheduled tribes and other traditional forest dwellers (Recognition of forest rights) Act, 2006. New Delhi: Government of India.

Mitra, K. R. (2009). Indigenous peoples’ Forest Tenure in India. In J. Perera (Ed.), Land and Cultural Survival: The Communal Rights of Indigenous People in Asia (pp. 193-211). Philippines: Asian Development Bank.

Nayak, R., Boal, B. M., \& Soreng, N. (1990). The Kondhs: A handbook for development. New Delhi: Indian Social Institute.

Padel, F., \& Das, S. (2010). Out of this earth: East India Adivasis and the Aluminium Cartel. New Delhi: Orient BlackSwan.

Patnaik, N. (1981). The Kondhs of Orissa: Their Socio-cultural Life and Development. Cuttack: Tribal and Harijan Research-cum-Training Institute.

Rose, D. (2005). An indigenous philosophical ecology: Situating the human. The Australian Journal of Anthjropology, 16(3), 294-305.

Roy Burman, J. J. (2009). Adivasi: A contentious term to denote tribes as indigenous peoples of India. Mainstream, XLVII(32), 1-7.

Sarkar, H. S. (1981). The Kutia Kondhs: A description of their lifestyle. Bhubaneswar: NISSWASS.

Saxena, N. C., Parasuraman, S., Kant, P., \& Baviskar, A. (2010). Report of the four member committee for investigation into the proposal submitted by the Orissa Mining Company for Bauxite Mining in Niyamgiri. New Delhi: Government of India.

Sundar, N. (2005). The construction and destruction of “Indigenous” knowledge in India's Joint Forest Management Programme. In R. Ellen, P. Parker, \& B. Bicker (Eds.), Indigenous Environmental Knowledge and its Transformations: Critical Anthropological Perspectives (pp. 79-100). Australia: Harwood Academic Publishers.

Thornberry, P. (2002). Indigenous peoples and human rights. Manchester: Manchester University Press.

United Nations. (2008). United Nations declaration of the rights of indigenous people. New York: United Nations.

Vedanta. (2015). The Lanjigarh development story: Vedanta's perspective. Retrieved from http://lanjigarhproject.sesasterliteodisha.com/The-Lanjigarh-Development-Story-Vedanta-Perspective.pdf

Wiessner, S. (2011). The cultural rights of indigenous peoples: Achievements and continuing challenges. The European Journal of International Law, 22(1), 121-140.

Xaxa, V. (1999). Transformation of Tribes in India: Terms of discourse. Economic and Political Weekly, 34(24), 1519-1524. 